\title{
El Hijo del hombre joánico. Una teología del martirio y de la exaltación ${ }^{1}$
}

\author{
César Carbullanca N. \\ UNIVERSIDAD CATÓLICA DEL MAULE
}

\section{Planteamiento}

La investigación sobre el sentido del título «Hijo del hombre» en el evangelio de san Juan muestra un panorama altamente confuso y que, al parecer, estamos todavía lejos de alcanzar una síntesis². La complejidad de la empresa proviene de los múltiples aspectos y problemas que debiera considerar una respuesta adecuada:

1) Un primer núcleo de problemas proviene de la cuestión de si el título «Hijo del hombre» en el evangelio de san Juan proviene de los escritos sinópticos o responde a una tradición independiente. Desde R. Bultmann los dichos sobre el Hijo del hombre sufriente fueron clasificados como una elaboración redaccional tardía de la comunidad postpascual $^{3}$; de modo consecuente, se ha tendido a estudiar la cristología del Hijo del hombre joánico haciéndolo derivar de este modelo sinóptico, esto es, que la significación del Hijo del hombre joánico habría que considerarla como una elaboración posterior a partir del uso sinóptico que se hace de este título. El hecho es que esta clasificación lleva a que

1 El artículo es parte del proyecto FONDECYT de iniciación $\mathrm{N}^{\circ}$ 11085038: El profeta escatológico. Estudio de los orígenes de la cristología del cuarto evangelio y del proyecto del FONDECYT regular N 1120029 «Martirio y exaltación del Hijo del hombre. Una teología del martirio judía y su recepción en los evangelios».

2 Cf. F. Moloney, The Johannine Son of Man (Eugene-Oregon, 1978) 1-22; B. Reynolds, The Apocalyptic Son of Man in the Gospel of John (Tübingen 2008), 1-10; G. C. Nicholson, Death as Departure. The johannine Descent-Ascent Schema (California 1983).

3 Cf. F. HaHn, Christologische Hoheitstitel (Göttingen ${ }^{5}$ 1995). 
algunos autores -como M. Black o R. Schnackenburg ${ }^{4}-$ hablen de una "cristología de la exaltación» como si fuese posible diferenciar aquella de otra relativa a la muerte de Cristo 5 . La cuestión no es fácil, si atendemos al estudio de textos neotestamentarios relativos a la Exaltación del Hijo del hombre, es claro que en algunos textos como Mc 14, 62; 13, 26 (par Lc 21,27) existe una concepción de su Exaltación entendida con relación a la vuelta del Hijo del hombre futuro ${ }^{6}$. Además, es bueno recordar que G. Lohfink ha probado que el esquema del «arrebato» fue utilizado para explicar la resurrección de Cristo ${ }^{7}$. Nosotros somos escépticos, junto con Nicholson, a derivar o clasificar los dichos joánicos a partir del esquema sinóptico ${ }^{8}$, estos no solo representa una tradición independiente, sino que se trata de una más primitiva interpretación de Dn 7,13 que la contenida en los sinópticos?

2) Un segundo núcleo de temas surge a partir del sentido que tiene el título "Hijo del hombre» en el evangelio de san Juan y, de modo específico, su relación con la exaltación. Un número grande de investigadores como P. Borgen, J. Bühner, J. Ashton creen asociar la figura del Hijo del hombre con el esquema ascenso-descenso. De acuerdo a J. Bühner, el estrato más antiguo lo constituye el material apocalíptico que presenta el esquema subir/bajar: «el estrato más antiguo de la cristología del cuarto Evangelio está determinado profético-ascendente» ${ }^{10}$. Bühner sostiene que la terminología del rapto (Entrückung) está vinculada con la terminología del ascenso/descenso propio del judaísmo tardío ${ }^{11}$. En este sentido, se vuelve crucial el significado del verbo ú $\psi o ́ \omega$, presente en la mayoría de los dichos del Hijo del hombre joánico, el que proviene con toda seguridad de Is 52, 13. Sin embargo, el término muestra una

4 Cf. R. Schnackenburg, Misterium Salutis, tomo III (Madrid 1999), 209.

5 Cf. M. Black, "The Son of Man Passion Sayings in the Gospel Tradition», en ZNW 60 (1969) 6-7; K. BERGER, Theologiegeschichte des urchristentums (Tübingen und Basel $\left.{ }^{2} 1995\right), 211$.

6 Cf. L. Goppelt, Theologie des Neuen Testaments (Göttingen ${ }^{3} 1991$ ), 372-375.

7 Cf. G. Lohfink, Die Himmelfaht Jesu. Erfindung oder Erfahrung (Stuttgart 1972), $9-12$.

8 Cf. G. C. Nicholson, Death as Departure, 61.

9 Cf. G. C. Nicholson, Death as Departure, 62.

10 J. A. BüHner, Der Gesandte und sein Weg im 4 Evangelium (Tübingen 1977), 415.

11 Cf. Jn 7, 33s.; 13, 31s.; 8, 21 s. 
ostensible ambigüedad que pretende -a juicio de autores como O. Cullmann- demostrar la simultaneidad e identidad del elevado en la cruz con el ser elevado al Padre ${ }^{12}$. La ambigüedad de dicha expresión radica -a juicio de Lüdemann- en que «el verbo úłó $\omega$ adquiere un significado especial en el contexto cristológico» ${ }^{13}$. Algunos -como F. Moloney- rechazan reiteradamente en su trabajo que en el cuarto evangelio no existe un esquema de ascenso-descenso, sino que el título "Hijo del hombre»

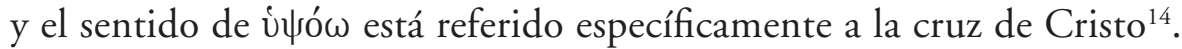
Afirma Moloney en contra de autores como Bühner: «yo estoy convencido que buscar en el mito del descenso-ascenso del redentor como background es buscar en lugar equivocado, ya que el Hijo del hombre joánico no está vinculado con el movimiento vertical» e insiste que la elevación ocurre en la cruz y "no continúa en los cielos» ${ }^{15}$. Por el contrario, U. Müller afirma que la terminología de la muerte de Jesús está fuera del campo visual del evangelista, de modo que "Juan pudo adoptar la terminología del arrebato porque su interés cristológico no está orientado a la muerte de Jesús, sino a la idea de la vuelta» ${ }^{16}$.

3) Un tercer aspecto emerge de la relación entre la cristología del Hijo del hombre y el contexto en el cual habría que inscribir dicha reflexión. A partir del trabajo de J. L. Martyn ${ }^{17}$ se entiende el evangelio de Juan como un "drama en dos niveles» en el que pasado y presente se unen en la narración. El presente de la comunidad está contextualizado en las disputas entre cristianos y judíos presentes en los textos, de tal manera que el sitz im Lebem de la cristología del Hijo del hombre es el conflicto con las autoridades judías ${ }^{18}$. En esta misma línea se mueve R. Brown y J. Painter. Para este último, la cristología del Hijo del hom-

12 Cf. O. Cullmann, The johannine Circle. Its place in Judaism, among the disciples of Jesus and in early Christianity (London 1976), 17; B. Reynolds, The Apocalyptic Son of Man, 117-118.

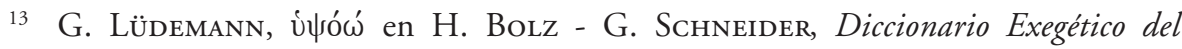
Nuevo Testamento. Tomo II (Salamanca 1998).

14 Cf. F. Moloney, The Johannine Son of Man, 226.

15 F. Moloney, The Johannine Son of Man, 229.

16 U. Müller, Die Bedeutung des Kreuzestodes Jesu im Johannesevangelium (Kerygma 1973), 55.

17 Cf. J. L. Martyn, The History \& Theology in the fourth Gospel (Nashville 1979).

18 T. HägerLand, John's Gospel: A Two-Level Drama, JSNT 25(2003)3, 312; E. W. KLINK III, The Gospel Community debate: State of the question, CBR 3. 1 (2004), 60-85. 
bre vendría a corregir una cristología deficiente. Respecto a las causas del conflicto, este cree que radican precisamente en la apropiación del Hijo del hombre aplicado al Cristo: "la identificación de Cristo con el celestial Hijo del hombre es lo que constituye la base de la acusación de blasfemia» ${ }^{19}$. Esto marcaría el paso de una mesianología judía a una cristología propiamente cristiana del Hijo del hombre y expresaría la raíz del conflicto (ver Hch 22, 19-20; 26, 10-11). No obstante estos avances, tenemos que señalar que la teoría de los estratos utiliza el contexto en el cual se desarrolla esta cristología meramente como un escenario en donde acontecen cuestiones literarias o teóricas, pero no posee una función hermenéutica propiamente tal y donde el conflicto con la sinagoga sería finalmente externo. A nuestro parecer tal contexto es de tal manera relevante que se constituye en un lugar teológico desde donde se elabora una cristología que responde a la situación que vive la comunidad joánica.

En nuestro artículo Orígenes de la Cristología joánica. Un estudio a partir de la tradición de $11 \mathrm{QMelq}^{20}$, hemos sostenido que la matriz ideológica del cuarto evangelio estaría relacionada con grupos apocalípticos judíos. Una matriz ideológica significa tanto experiencia como reflexión teológica, la cual funciona como dispositivo esperanza que moviliza a un colectivo, de tal manera que las expresiones «Hijo del hombre», «Hijo», «enviado» representan verdaderos "pactos comunicativos o pragmáticos» para movilizar la esperanza de los integrantes de una comunidad ${ }^{21}$. En estos grupos, experiencia y reflexión teológica son dos aspectos indisolubles: a la experiencia de la persecución se une una teología del martirio

19 J. Painter, «The Point of John' Christology», en D. Horell - C. Tuckett, Christology, Controversy and Community. New Testament Essays in Honour of David R. Catchpole (Leiden 2000), 251; M. De Jonge, «Christology, Controversy and Community in John», en D. Horell - C. Tuckett, Christology, Controversy and Community. New Testament Essays in Honour of David R. Catchpole (Leiden 2000), 221. En Teología y Vida L (2009), 567-597.

21 Cf. B. Malina, O evangelho social de Jesus. O reino de Deus em perspectiva mediterránea (São Paulo 2004), 15. Dice Malina: «Lo que estoy sugiriendo es que la Biblia es necesariamente mal comprendida si algún lector de ella no está fundamentado en una apreciación del sistema social en los que sus documentos surgieron [...] Todas las actitudes, valores e interacciones conductuales descritas en la Biblia son necesariamente mal comprendidas -o no son simplemente comprendidas- sin alguna apreciación y entendimiento del sistema social declarado y reflejado en los escritos bíblicos». 
que integra tanto el motivo de la exaltación como el del martirio del profeta escatológico.

El artículo pretende desarrollar el contexto en que se elabora esta cristología y explica las principales características presentes en los dichos del Hijo del hombre joánico sosteniendo que estos provienen de una tradición relativa al martirio del pueblo originada en ambientes judíos y que, por tanto, dicha praxis martirial constituye un lugar teológico que pretende una legitimación de la esperanza en una futura exaltación frente a un judaísmo que persigue, excomulga y asesina a miembros de la comunidad joánica. Por tanto, la hipótesis pretende mostrar que entre lugar teológico y elaboración teológica hay una vinculación pragmática de tal modo que, tanto el recurso a la tradición del martirio como el contexto de persecución, muestran aspectos más determinantes de los que proponen L. Martyn y R. Brown. A nuestro parecer, no se trata tan solo de situar una reflexión teológica de modo independiente a sus formulaciones, sino que la experiencia de persecución funciona como lugar teológico desde donde la comunidad joánica desarrolla una teología de su esperanza en la exaltación de modo similar a la de grupos apocalípticos del judaísmo. En nuestra investigación, explicamos cada uno de los dichos sobre el Hijo del hombre concluyendo que todos ellos están relacionados con la idea de la superioridad del Hijo del hombre -y particularmente su muerte- frente a todas las instituciones judías. Desarrollamos posteriormente una síntesis cristológica exponiendo diferentes temas contenidos en los dichos: la utilización de esquemas míticos y la cristología del Hijo del hombre; la existencia de una cristología prejoánica del martirio y exaltación, la cual es utilizada por el evangelista; el contexto en que se desarrolla esta cristología; la relación entre la muerte del Hijo del hombre y el uso de uభów y la cuestión del sentido de la preexistencia del Hijo del hombre en el cuarto evangelio.

\section{Contexto de la comunidad joÁnica}

\subsection{El contexto histórico y lugar teológico}

El cuarto evangelio entrega indicaciones notables acerca de la situación de marginalidad o polémica en la cual ha nacido y se ha desarrollado la comunidad joánica. Este contexto varía a través de la historia de la comunidad joánica, pero se mantiene en aspectos esenciales: marginalidad 
y persecución. Esta situación es algo más que un contexto en donde se desarrollan disquisiciones teóricas mesiánicas o cristológicas, más bien se trata de un "pacto pragmático" que explica la figura del Hijo del hombre. Si atendemos a los primeros materiales, tanto a los capítulos 1-2 y 4 vemos que tanto la participación de discípulos del Bautista como de miembros samaritanos en la comunidad joánica apunta a este mismo aspecto. Este origen marginal expresa un aspecto ideológico importante que posteriormente se decantará aún más. La expectativa que profesan estos grupos es la del profeta escatológico como Moisés.

Afirma J. Painter que la cristología joánica es una cristología que de modo inevitable lleva al conflicto ${ }^{22}$. Este autor señala que Juan ha desarrollado a partir de 5, 1-18 el paradigma del rechazo de los judíos ${ }^{23}$, pero debemos decir que ya previo al conflicto con la sinagoga judía los materiales más tempranos del evangelio muestran que la comunidad joánica estaba integrada por samaritanos y miembros de la secta de Juan Bautista, quienes profesaban una expectativa similar a la de los «helenistas» de Hch 7, lo que les significó ser expulsados y perseguidos ${ }^{24}$. La cristología alta que encontramos en los siguientes capítulos expone una ideología más radicalizada que la anterior, que se desarrolla en su enfrentamiento con la sinagoga alrededor de los años $80 \mathrm{~d}$. C. En una posterior etapa, los miembros de la comunidad son odiados por el mundo (Jn 17, 14), excomulgados de la sinagoga $(9,42.34)$ o matan a sus seguidores $(12,10)$. Esto tiene su origen en la hostilidad que rodea al mismo Jesús a quien persiguen $(5,16)$, intentan apedrear $(\mathrm{Jn} 8,59 ; 10,10.31)$, matarlo $(5,19 ; 7,1 ; 11,53)$; además es acusado de blasfemar el nombre de Dios (Jn 10, 33. 36; 5, 18) ${ }^{25}$.

Painter se pregunta por las causas del conflicto e indica que la acusación de los sinópticos cae sobre la blasfemia: «la identificación de Cristo con el celestial Hijo del hombre es lo que constituye la base de la acusa-

22 Cf. J. Painter, «The Point of John' Christology», 231.

23 Cf. J. Painter, The Quest for the Messiah. History, Literature and Theology of the Johannine Community (Edinburgh 1991), 175.

24 Cf. O. Cullmann, The johannine Circle, 43-46. Es importante notar cómo el texto de Hch 7 contiene tres elementos importantes para nuestra discusión. Primero, Esteban utiliza el texto de Dt 18, 15 para expresar la expectativa mesiánica del profeta escatológico aplicado a Jesús de Nazaret (v. 39); segundo, el discurso termina viendo al Hijo del hombre a la derecha de Dios (v. 56); y tercero, el contexto de persecución $(8,1)$.

25 Cf. B. Lindars, Behind the Fourth Gospel (London 1971), 70. 
ción de blasfemia» ${ }^{26}$. Este paso de una mesianología judía a una cristología del Hijo del hombre expresaría la raíz del conflicto ${ }^{27}$. Esto revela un aspecto significativo que tendremos en cuenta en nuestra discusión. Los orígenes de la cristología joánica proceden de grupos marginales apocalípticos perseguidos y martirizados, los cuales comparten con la comunidad joánica un mismo "pacto pragmático». Por esto, como lo veremos, la cristología del Hijo del hombre no es una cristología distinta elaborada en "fase posterior" a la cristología del enviado y a la ya presentada en otro artículo acerca del profeta escatológico. Hay que decir que pertenece a un mismo lugar teológico: grupos radicalizados a la luz de la experiencia del martirio que sufre la comunidad y que fundamentan su esperanza desde esta situación de persecución.

\subsection{El conflicto entre Jesús y el mundo}

La situación conflictiva entre los miembros joánicos y la sinagoga judía emerge a raíz de la confesión de Jesús mesías como Hijo del hombre. Este punto es importante porque muestra que los primeros cristianos elaboraron su confesión de fe desde una situación de persecución recurriendo a un pensamiento mitológico sobre un ser celeste enviado por Dios para realizar el juicio en el mundo, utilizado por círculos apocalípticos marginales del judaísmo tardío. Para estos grupos, «el mundo» es esencialmente tinieblas, mentira y esclavitud ${ }^{28}$. El odio en el que viven los que no reciben la luz no es visto desde la perspectiva meramente humana, sino que representa una cosmovisión apocalíptica según la cual el kosmos y todo hombre está bajo el poder del maligno (ver 8, 44; 14, 30).

Esta estructura mítica representa una ideología contraria a la de un judaísmo más oficial, pues sostiene una actitud crítica frente a las instituciones defendidas por el judaísmo rabínico tales como el templo, el sacerdocio, la ley y los ángeles. En este contexto cabe destacar la cantidad de expresiones sobre la relación de odio por parte del mundo a los discípulos y a Jesús que presenta el cuarto evangelio. Nos parece que estas

26 J. Painter, «The Point of John' Christology», 251; M. De Jonge, «Christology, Controversy and Community in John», 221, en D. Horell - C. Tuckett, Christology, Controversy and Community. New Testament Essays in Honour of David R. Catchpole (Leiden 2000), 221; O. Cullmann, The johannine Circle, 17.

27 Cf. Hch 22, 19-20; 26, 10-11.

28 Cf. R. Bultmann, Teología del Nuevo Testamento (Salamanca 1999), 430-431. 
expresiones muestran una situación vital y el lugar teologal desde donde habla y confiesa su fe la comunidad joánica. La primera noticia de esta situación la tenemos en Jn 7, 7: «el mundo no puede odiaros a vosotros; pero a mí me odia ( $\mu\llcorner\sigma \in \hat{\imath}) »$. Sin embargo, a partir de los capítulos 15-16 se aprecia una preocupación por la fidelidad de los discípulos porque se acerca el tiempo de la prueba. Lindars afirma que «[...] nosotros debemos ver aquí la amenaza de la persecución judía a los cristianos, más que la del poder del imperio romano» ${ }^{29}$. Este cambio de énfasis puede reflejar un deterioro de las relaciones judeocristianas. Los capítulos 1517 pretenden dar cuenta que el odio del mundo radica en que primero han odiado a Jesús y muestran también la lógica del mundo: odio-persecución-muerte. En Jn 15, 18-20 dice: «Si el mundo os odia, sabed que a mí me ha odiado antes que a vosotros». Esta secuencia se completa a continuación en Jn 16, 1-2: «Los expulsarán de las sinagogas, y aun viene la hora cuando cualquiera que os mate pensará que rinde servicio a Dios». M. de Jonge, de igual manera que Painter, dice algo similar en relación al capítulo 17 al afirmar que es «la concreta circunstancia de la comunidad joánica» ${ }^{30}$. Este odio no es solo verbal, sino que se expresa como persecución, expulsión de la sinagoga e incluso martirio de algunos cristianos, como se afirma en Jn 15, 20.

\section{LOS DICHOS DEL HIJO DEL HOMBRE JOÁNICO}

Este contexto de persecución y odio contra Jesús y los suyos queda reflejado en la cristología del Hijo del hombre elaborada por el evangelista. La cristología del Hijo del hombre por tanto pretende ser un principio esperanza que responde a la situación que sufre la comunidad joánica. Las reflexiones que siguen apuntan a establecer una vinculación entre el uso de esta expresión con el lugar martirial de la comunidad joánica, así como con el trasfondo apocalíptico del cual pensamos procede la misma. Un aspecto importante que es necesario indicar desde un principio es el paso desde una expectativa mesiánica judía del profeta escatológico a una cristología del Hijo del hombre. Dicho esto, diversos autores han realizado la clasificación de los dichos acerca del Hijo del hombre; clasi-

29 B. Lindars, Behind the Fourth Gospel, 77.

30 M. Jonge, Jesus: the Stranger of Heaven and Son of God (Missoula 1977), 154-155. 
ficación que no deja de ser diversa según los autores que se consulten ${ }^{31}$. No obstante estos, a juicio de destacados investigadores como Coppens y Schnackenburg, los dichos integran un círculo unitario de ideas que muestran una única cristología ${ }^{32}$.
1,51 y 3,13
usan los términos subir y descender del Hijo del hombre ( $\alpha \nu \alpha \beta \alpha i \nu 0 \nu \tau \alpha \varsigma \kappa \alpha i \kappa \kappa \tau \alpha \beta \alpha i \nu 0 \nu \tau \alpha \varsigma)$

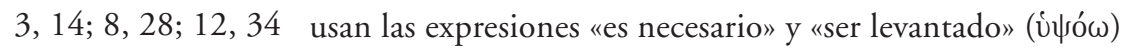
6, 62 y 6,62 la preexistencia del Hijo del hombre, «subir» y "primero»

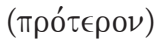
5, 27 la autoridad para hacer el juicio del Hijo del hombre

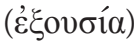
9, $35 \quad$ creer en el Hijo del hombre ( $\pi\llcorner\sigma \tau \in \dot{\epsilon} \in\llcorner$ )

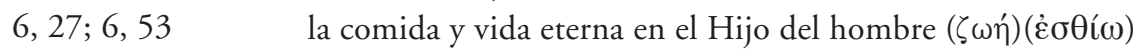

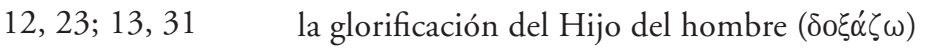

\subsection{El dicho de Jn 1, 51}

El primer texto que menciona al Hijo del hombre es Jn 1, 51 que está en un contexto de diálogo con los discípulos; en el v. 50 se les promete "ver cosas mayores», lo mismo que en 5, 20: «...Y mayores obras que estas le mostrará, de modo que vosotros os asombréis». La expresión « $Y$ mayores obras que estas le mostrará» expresa un referente no mencionado en el futuro ${ }^{33}$. El asombro remite a una etapa que será superada, marcando el paso de la expectativa mesiánica judía a la cristología del Hijo del hombre. Por eso, a continuación coloca en el centro de lo no expresado la figura del Hijo del hombre de 1, 51: «Y les dijo: -De cierto, de cierto os digo que veréis (’o $\psi \epsilon \sigma \theta \epsilon)$ el cielo abierto y a los ángeles de Dios que suben y descienden ( $\alpha \nu \alpha \beta \alpha i ́ \nu 0 \nu \tau \alpha \varsigma \kappa \alpha i \quad \kappa \alpha \tau \alpha \beta \alpha i \nu o \nu \tau \alpha \varsigma)$ sobre el Hijo del hombre». Este dicho «amén» de Jesús se presenta como el punto más alto de toda la unidad y como clave hermenéutica para comprender lo que sigue. El dicho amén de Jesús es un dicho profético y la expresión «veréis» (’’ $\psi \in \sigma \theta \epsilon)$-así como en 6, 67- es una visión frecuente en narraciones apocalípticas, que representa una prognosis de los aconteci-

31 Cf. J. Coppens, «Le Fils de L'Homme dans L'evangile Johannique», EpThL LII (1976), 33; R. Schnackenburg, Das Johannesevangelium 1-4 (Freiburg 1979), 412.

32 R. Schnackenburg, Das Johannesevangelium, 414.

33 R. Maddox, "The Function of the son of Man», en R. Banks, Reconciliation and Hope. New Testament Essays on Atonement and Eschatology (Michigan 1974), 191. 
mientos futuros. La visión de los «cielos abiertos» y los «ángeles de Dios bajan y suben por la escala de Jacob» recuerdan el texto de Gn 28, 19, y muestra la idea -frecuente en estos círculos- acerca de una revelación actual, lo cual resulta contrario a la teología presente en grupos rabínicos contemporáneos. La prognosis de Jn 1, 52 tiene dos miembros: «los cielos abiertos» y los «ángeles de Dios subiendo y bajando sobre el Hijo del hombre», que recuerdan a Mc 14, 62, donde se relaciona la pretensión mesiánica con la visión del Hijo del hombre de Dn 7, 13. En este mismo texto, el punto de vista es una retrospectiva de los hechos, pero a diferencia de aquel, el acontecimiento del Hijo del hombre está situado en el futuro y los sujetos de tal visión son los discípulos. Es importante recalcar que, al igual que la afirmación de Jn 3, 13, se identifica como lugar del juicio no los cielos sino la tierra. Además, tanto el relato de 1, 51 como 3, 13 utilizan el esquema de correspondencia "abajo/arriba»" ${ }^{34}$ y que hemos detallado en otro artículo ${ }^{35}$, pero lo corrige señalando que la escala descansa no en la tierra sino sobre el Hijo del hombre, lo que indica un cambio premeditado. Pero no solo esto. Al indicar que el «lugar de encuentro» entre Dios y los hombres ya no es Betel (ver Gn 28, 19), sino el Hijo del hombre el carácter futuro de la visión remite a toda la vida del Hijo del hombre hasta la muerte de este ${ }^{36}$. En esto reconocemos la intención del evangelista de colocar la futura muerte del Hijo del hombre por sobre los ángeles y las instituciones y personajes del pasado ${ }^{37}$. La imagen del descenso de los ángeles sobre el Hijo del hombre muestra un presupuesto propio de la apocalíptica que J. Ashton asume citando a M. R. James: «los ángeles pueden encarnarse en cuerpos humanos, vivir sobre la tierra a semejanza de los hombres ${ }^{38}$. Este presupuesto teológico creemos está en la base de la reflexión acerca de la encarnación del logos joánico.

Como está dicho, la figura del Hijo del hombre en cuanto hombre y mártir, representa una etapa superior en relación a la historia del AT.

34 Cf. W. Meeks, The Man from Heaven in Johannine Sectarianism: JBL 91 (1972), 50-51.

35 Nota 19.

36 Cf. A. Higgins, Menschensohn Studien (Stuttgart 1965), 26; B. Lindars, Jesus son of Man (Michigan 1983), 147.

37 Cf. B. Lindars, John (England 2001) 84; R. Brown, Giovanni (Assisi 1999), 179.

38 A. Ashton, Understanding the Fourth Gospel (1993), 344. 
Así lo expresa el dicho: "mayores obras que estas le mostrará». El acontecimiento futuro está referido a la muerte del Hijo del hombre. La teología europea -como la de J. Painter- se centra en demostrar que la cristología del Hijo del hombre es una cristología que sirve para corregir otras designaciones mesiánicas judías incompletas. Por eso Painter señala que "la auténtica fe es solo posible cuando el discípulo ha visto a Jesús como el Hijo del hombre, exaltado a los cielos por medio de la cruz y entronizado como el celestial rey» ${ }^{39}$. A nuestro juicio, es una manera individualista y descontextualizada de estudiar la cristología joánica, entendiendo la muerte de Cristo sin relación al contexto social o político de las afirmaciones o términos que se utilizan. En realidad, el autor no intenta corregir una cristología deficiente, transformando a esta en otra cristología dentro del mismo evangelio, sino que esta es un "pacto lingüístico" propio de grupos marginales perseguidos y martirizados, que fundamentan su esperanza en una futura exaltación y la han radicalizado mediante la figura del martirio del Hijo del hombre.

\subsection{El dicho de Jn 3, 14}

Para B. Lindars este versículo es el origen de todos los demás dichos joánicos del Hijo del hombre. P. Borgen sostiene que el v. 13 está criticando a «un entorno joánico» que consideraba dentro de esta categoría a otros visionarios como Elías y Moisés ${ }^{40}$.

El texto de Jn 3, 14 es dirigido a un representante judío (v. 1), pero el v. 11 muestra un cambio de primera persona singular a primera persona plural. La sección vv. 11-21 está expresada en el estilo nosotros de la última redacción, lo cual muestra que Jesús habla en nombre de la comunidad joánica y Nicodemo representa al vosotros de la sinagoga. Los siguientes versículos, por consiguiente, es necesario verlos en este contexto fundamental de polémica con la sinagoga. De acuerdo a esto, los vv. 13-14, es decir, el estilo nosotros, es responsable del uso de úభó $\omega$ : "Nadie ha subido al cielo, sino el que descendió del cielo, el Hijo del hombre. Y como Moisés levantó la serpiente en el desierto, así es nece-

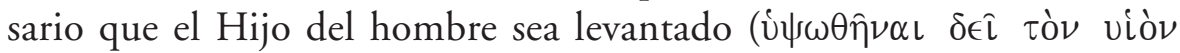

39 J. Painter, «Christ and the Church in John 1, 45-51», en M. De Jonge (ed.), L'Evangile de Jean. Sources, redaction, theologie (Leuven 1977), 31.

40 Cf. P. Borgen, «Some Jewish exegetical tradition as Background», en M. De Jonge (ed), L'Evangile de Jean. Sources, redaction, theologie, 244. 


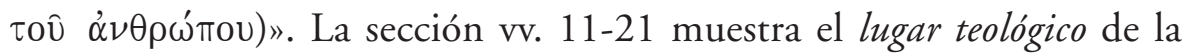
comunidad, expresada en el estilo nosotros, lo cual revela que es «la comunidad joánica quien relata los hechos a nombre de Jesús» y Nicodemo representa al vosotros de la sinagoga que ha excomulgado y asesinado a miembros del grupo joánico. En los vv. 10-11 muestra el principio de ignorancia característico de grupos apocalípticos: "Jesús le respondió: Tú, que eres el maestro de Israel, ¿no sabes esto? 11. De cierto, de cierto te digo que de lo que sabemos, hablamos, y de lo que hemos visto, testificamos; pero no recibís nuestro testimonio» (ver Jn 9, 39; 12, 40).

En el v. 14 el uso de la partícula $\delta \in \hat{\imath}$ muestra una perspectiva apocalíptica de los eventos narrados similar a la encontrada en Mc 8, 31. Pero, sobre todo, es notable en este dicho que la figura de Moisés aparezca asociada a la del Deuteroisaías a través del uso del verbo ú\}ów / ירום «levantar», «elevar» ${ }^{41}$. Esta cita muestra claramente la transferencia de los atributos del profeta escatológico, Moisés, a la figura del Hijo del hombre. La cita reúne la tríada: Moisés-siervo de Yahvéh-Hijo del hombre. $\mathrm{Al}$ respecto es importante notar la imagen angelomórfica de Moisés que presenta la literatura del judaísmo tardío ${ }^{42}$. En Antigüedades Bíblicas, la muerte de Moisés es acompañada por el silencio y asombro de los ángeles y en 4Q377 el profeta es un elohim y mesías por sobre los ángeles. Esta alta valoración de Moisés, el siervo de Dios, por sobre los ángeles muestra -a nuestro juicio- un desarrollo durante este periodo de una teología del martirio que expresa que siervos como Moisés o Elías, que murieron por su fe, están por sobre los ángeles. De acuerdo a la opinión de M. Black y G. Nickelburg el hecho que ưłów aparece también en Fil 2, 9; Hch 2, 33; 5, 31 -los cuales muestran el mismo tipo de "cristología de la exaltación»- señala que «Is 52, 13 -aplicado al Hijo del hombreha circulado como un testimonio independientemente y antes que el cuarto evangelio lo adoptara y adaptara $»^{43}$.

41 Acerca del sentido de la expresión hacemos referencia a la síntesis de B. Reynolds, The Apocalyptic Son of Man, 122-127.

42 Cf. AntBíblicas 19, 16; 4Q377

43 M. Black, «The Son of Man Passion Sayings in the Gospel Tradition», en $Z N W 60$ (1969) 6-7; G. Nickelburg, Resurrection, Inmortality, and Eternal Life in Intertestamental Judaism and Early Christianity. Expanded Edition (New Haven 2006), 3942; J. BlaCK, Krisis. Untersuchungen zur johanneischen Christologie und Eschatologie (Freiburg 1964), 80. J. Blank responsabilizan al evangelista de la introducción del concepto de úłów «exaltación»; J. Coppens, «Les Logia Johanniques du Fils de 
A propósito del v. 13, diversos autores han subrayado el carácter polémico del dicho ${ }^{44}$. El estilo nosotros es un claro indicador de este hecho. Algunos autores identifican a estos adversarios con la sinagoga, otros con judíos o cristianos que aceptaban la existencia de visionarios semejantes a Moisés, pero es difícil pensar que el evangelista esté polemizando con el judaísmo rabínico más estricto que se negaba a aceptar este tipo de revelación. Más bien pareciera que este dicho está dirigido a un tipo de judaísmo sincretista que aceptaba la mediación de ángeles o visionarios a quienes se les consideraba sujetos de revelaciones divinas. Por esto, al parecer, la pretensión del evangelista es fundamentar la esperanza y fundamentar esta, por lo cual, la cristología del Hijo del hombre coloca

L'Homme» en M. De Jonge (ed.), L' Evangile de Jean. Sources, redaction, Thèologie, 313. J. Coppens sostiene que los estratos del Hijo del hombre corresponden al evangelista o a un redactor posterior, y serían una relectura profunda de relatos isaianos, «sobre todo de las perícopas deuteroisaianas y daniélicas». Por nuestra parte, creemos importante atender al uso de ירומם y, en general, de Is 52, 13 durante el periodo del judaísmo tardío, el que se puede pesquisar a partir de esta etapa, p.ej. en el texto de los LXX Dn 11, 36: «El rey hará su voluntad, se ensoberbecerá y se engrandecerá (ì $\psi \omega \theta \eta$ ńsetai) sobre todo dios»; y en 12, 3: «en aquel día será

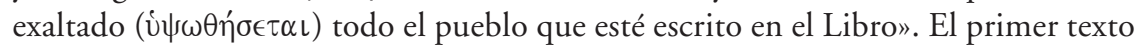
está en relación a la soberbia del corazón del rey, pero el segundo tiene un sentido colectivo, está en relación a la resurrección escatológica no de un individuo, sino de todo el pueblo. El texto de los LXX Dn 12, 3 traduce "liberar», según el texto masorético, por ú $\psi \omega \theta \eta \dot{\sigma \epsilon \tau \alpha \iota ~ « e x a l t a r » ~ t e n i e n d o ~ c o m o ~ s u j e t o ~ a l ~ p u e b l o ~ d e ~ l o s ~}$ santos; esto mismo lo encontramos en un texto contemporáneo, la AscMoisés 10, 9: «[...] y Dios te exaltará (Israel) y hará vivir en las estrellas del cielo». El contexto -tanto del libro de Daniel como el de Ascensión de Moisés» remite a la persecución de los maskilim y del pueblo de los santos. A juicio de Nickelburg, el texto de la Ascensión de Moisés es más cercano que Dn 12, 3 a la tradición de Is 52, 13, ya que este último habla de "transformación a las estrellas» en cambio el texto de AscMoisés 10, 9 trata de «exaltación» como el texto isaiano. Nosotros tenemos que añadir a esta enumeración de Nickelburg la de 4Q491ㄷ. Tanto en el caso de AscMoisés 10, 9 como en el de 4Q491' , encontramos una tradición que vincula la persecución y sufrimiento al de una futura exaltación (ירומם/ن̛́w), esquema que encontramos aplicado en el cuarto evangelio a la figura del Hijo del hombre. Pero, a diferencia de AscMoisés 10, 9, en 4Q491 ${ }^{\mathrm{c}}$-donde se trata del pueblo de los santos o de un personaje como el profeta escatológico- en el cuarto evangelio se remite al Hijo del hombre. En el texto de Jn 3, 13, tanto el uso del lenguaje apocalíptico, como del pasaje de $\mathrm{Nm}$ 21, 9; Is 52, 13, muestran un rasgo del estilo nosotros. Claramente hay que decir que en la tradición apocalíptica el uso del texto isaiano o su tradición es uno de los medios para expresar la exaltación del siervo o profeta mosaico. 
a este por sobre todos los referentes religiosos: ángeles, ley, y templo. En cada uno de los pasajes donde se muestra la superioridad ${ }^{45}$ del Hijo del hombre en relación con los grandes antepasados o instituciones judías, se vislumbra el uso de ú $\psi o \omega ́$ joánico. Paradójicamente, la superioridad de Jesús en relación con la apocalíptica y la mediación de ángeles como Gabriel, Miguel y otros, se sitúa en la radicalidad del envío, es decir, la radical solidaridad, la encarnación y muerte del Hijo del hombre.

\subsection{El dicho de Jn 5, 26-27}

El dicho está colocado en el contexto polémico de una sanación en presencia de los judíos y en día sábado (v. 1. 10). El redactor coloca un paréntesis en los vv. 3-4: «En estos yacía una multitud de enfermos, ciegos, cojos y paralíticos, que esperaban el movimiento del agua, porque un ángel descendía de tiempo en tiempo al estanque y agitaba el agua». La propuesta de Jesús al enfermo en el v.6 «¿Quieres ser sano?» -en este contexto cultural- contiene una polémica con esta creencia, pero además el v. 9 coloca la cuestión de la acción de sanar en sábado. El v. 10 deja en evidencia el conflicto: «Entonces los judíos dijeron a aquel que había sido sanado: -Es sábado; no te es permitido cargar tu camilla». El v. 12 apunta a la identidad del que ha hecho la sanación. En los vv. 1618 se señala la razón de la polémica: «Por esta causa los judíos perseguían a Jesús e intentaban matarlo, porque hacía estas cosas en sábado. Jesús les respondió: -Mi Padre hasta ahora trabaja, y yo trabajo. Por esto los judíos aún más intentaban matarlo, porque no solo quebrantaba el sábado, sino que también decía que Dios era su propio Padre, haciéndose igual a Dios». Por consiguiente, el logion de 5, 26 está contextualizado en la pretensión de Jesús de estar por sobre la Ley y la cultura judía. En este contexto es significativo, entonces, que el v. 26 esté en relación al texto de Dn 7, 13. La expresión de Jn 5, 20 «y mayores obras que estas le mostrará, de modo que vosotros os admiréis» también la encontramos en 1, 50 y remite a este significado, esto es, la superioridad del Hijo del hombre respecto al sábado.

Es importante notar que en los vv. 26-27 se ha utilizado tanto el término vios como el título viòs $\alpha \nu \theta \rho \omega ́ \pi 0 v$. Es interesante la formulación porque el título vios expresa la singularidad del Hijo del hombre y, por consiguiente, la diferencia con respecto a otros personajes del pasado

45 Cf. B. Lindars, John, 78-80. 
radica en tener «vida en sí mismo»y poder para realizar «el juicio» ${ }^{46}$. Hay diversos textos neotestamentarios como Mc 1, 11; 9, 11; 12, 9; $\mathrm{Hb}$ 1, que muestran el término Hijo o "hijo amado» como expresión que destaca la superioridad de Jesús en relación a otros profetas y seres celestiales. Por eso es muy significativo que vios esté en relación al texto de Dn 7, 13. Desde un punto de vista lingüístico, dado que falta el artículo, algunos autores postulan que habría que traducir sencillamente por «hombre»; no obstante, su vinculación al título «Hijo» en este texto no deja lugar a duda que se trata de una expresión no solo honorífica sino de superioridad. Así también Ch. Barret sostiene que el término posee un sentido "cualificado ${ }^{47}$ dada la coincidencia con Dn 7, 14 de la

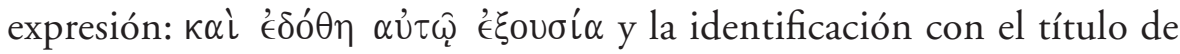
«Hijo» vios en el v. 26.

\subsection{Los dichos de 6, 27. 53. 62}

En el capítulo sexto existen tres dichos sobre el Hijo del hombre (ver 6, 27. 53. 62). P. Borgen ha sostenido la existencia de una homilía del éxodo en este capítulo que expresaría una corrección a una mesianología judía centrada en el profeta escatológico demasiado humana, cuya inserción el evangelista corregiría ${ }^{48}$. El dicho muestra que la carne y sangre del Hijo del hombre tienen vida en sí mismo. Esta terminología se relaciona con los dichos egóticos que muestran la diferencia entre el enviado que tiene vida en sí misma -vida eterna- y las anteriores instituciones judías que son mortales y no tienen origen divino. Las referencias a la pascual del Hijo del hombre son importantes en este capítulo: 6, 4. 17. 22. 4951. 58. El capítulo alude en diversos lugares a la pascua entendida como "fiesta», pero también como "cruzar» y "comer» la carne del Hijo del hombre. Es importante notar que la expresión «la carne» ( $\dot{\eta} \sigma \alpha ́ \rho \xi)$ que se repite siete veces ${ }^{49}-y$ que está en relación al importante versículo14 del prólogo ${ }^{50}-$, no es un concepto metafísico sino que describe al hombre

46 Cf. B. Lindars, Jesus son of Man, 153.

47 Ch.K. Barret, El evangelio según san Juan (España 2003), 386.

48 P. Borgen, "John 6: Tradition, Interpretation and Composition», en Martinus C. De Boer (ed.), From Jesus to John. Essays on Jesus and New Testament Christology in Honour of martinus de Jonge (Scheffield 1993), 278-279.

49 Cf. 6, 51. 52. 53. 54. 55. 56; 1Jn 4, 2; 2Jn 1, 7.

50 Expresiones semejantes de Pablo cf. 2Cor 5, 21; 2Cor 8, 9; Gál 3, 13 
histórico enajenado, por estructuras sicosociales que lo oprimen $(12,31)$. Esto nos lleva a afirmar con B. Lindars que el relato está orientado a la comunión con la condición oprimida y martirial del Hijo del hombre: «el lenguaje es eucarístico, pero la referencia es ciertamente a la pasión como el esencial factor de la cristología ${ }^{51}$.

En el primer dicho (v. 27), se puede apreciar que está dirigido a la

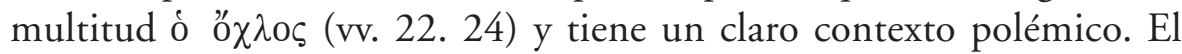
segundo dicho (v. 53), en continuidad con el v. 51, tiene relación con la muerte del Hijo del hombre, pero -como lo hemos señalado- el texto presenta diversas menciones de la pascua. Además, es interesante que el v. 32 contenga una relativización del papel mediador de Moisés. De estos tres dichos, el último está relacionado con la preexistencia del Hijo del hombre, en cambio, los primeros dos remiten al tema de que el Hijo del hombre «tiene vida en sí mismo». Como más adelante lo señalaremos, el término joánico «vida» está en el contexto de las expresiones egóticas del cuarto evangelio. En el logion de Jn 6, 58 «Este es el pan que descendió del cielo. No como los padres que comieron y murieron, el que come de este pan vivirá para siempre», muerte y vida eterna son términos relativos que giran en torno al tema del «creer» $\mathrm{y}$ «comer la carne del Hijo del hombre». Esta polaridad compendia tanto la terminología de la muerte de los antepasados como la de aquellos que creen en el Hijo del hombre.

Nos interesa subrayar el origen apocalíptico de estos dichos acerca del Hijo del hombre, a pesar que el tema es discutido ${ }^{52}$. Podemos decir lo siguiente: el dicho de 6, 62 muestra el uso del verbo $\theta \epsilon \omega \rho \epsilon ́ \omega$ que encontramos en textos apocalípticos; así también encontramos el uso de la terminología «subir» ( $\alpha \nu \alpha \beta \alpha i ́ v o \nu \tau \alpha)$ y «primero» en el tercero de ellos, lo cual remite a su preexistencia y a la acción de bajar. En los dichos de los vv. 33.50 se menciona que el pan que ha bajado del cielo ( $\kappa \alpha \tau \alpha \beta \alpha i \nu \omega \nu)$. Para Reynolds, el relato posee al menos algunos aspectos apocalípticos. Pero si atendemos a tradiciones apocalípticas podemos ver que existen dos modelos para describir el envío/encarnación de un emisario celeste ${ }^{53}$ : uno temporal, en donde se trata de un הוא אנוש "llegar a ser hombre»o "convertirse», que es posible traducirlo usando el término yírvouaı; la

51 Cf. B. Lindars, Jesus son of Man, 152; J. Dunn, "John VI- A Eucharistic Discourse?», en NTS 17(1970) 331; B. Reynolds, The Apocalyptic Son of Man, 157.

52 Cf. B. Reynolds, The Apocalyptic Son of Man, 147.

53 Cf. 1 Enoc 89, 1. 36. 38; 90, 6-19. 22. 31; 4Q204 fr. 4, 10; TestAbraham 7, 3-9. 
otra, es espacial y consiste en el "descenso", "bajar» de un "hombre» (be'si), el cual es equivalente al tema de la encarnación del mensajero. Ambos términos son utilizados en un contexto histórico de martirio y persecución del pueblo de los santos y tienen la función de fundamentar la esperanza y la lucha de estos grupos. El esquema que se utiliza en los relatos es diverso a través del cambio de era, se emplean diversas imágenes y conceptos para describir el envío o bajada un personaje celeste a la tierra, los ángeles llegan a ser "hombres», mientras los humanos son representados como animales ${ }^{54}$. A su vez, es importante mencionar que en tradiciones rabínicas la costumbre de expresar la acción de Dios mediante términos antropomórficos como la «bajada» de seres celestes fue considerada herética. Por otra parte, la expresión de «tener vida en sí mismo» manifiesta una prerrogativa divina que evidentemente levantó sospechas en la teología judía. En tradiciones apocalípticas como 1 Enoc 90, 6-19, la terminología del «hombre» tiene como función liberar y salvar al pueblo martirizado. Este descenso de seres celestes es considerado como una abreviación o sinónimo del concepto de encarnación: «su encarnación es lo que distingue al Hijo del hombre de Gabriel, Miguel y otros ángeles de los cuales el itinerario es superficialmente el mismo que él. Ho katabas ek tou ouranou es, entonces, la abreviatura de Juan para referirse a la encarnación» ${ }^{55}$.

\subsection{El dicho de Jn 8, 28}

El dicho de Jn 8, 28 está en un contexto polémico sobre la luz del mundo. Los vv. 12-59 -en contra de los fariseos y judíos (vv. 12. 13. 22)- son los relatos más violentos del evangelio y la polémica comienza respecto a la ley de los judíos (v. 17) y termina con una declaración acerca de la preexistencia del Hijo del hombre. El narrador sitúa la polémica en el templo, en el lugar de las ofrendas (v. 20). El relato muestra lo extremadamente aguda que es la polémica: tanto Jesús como los judíos hablan uno de otros en términos descalificatorios. En Jn 7, 18; 8, 37. 40 se menciona la intención de matar a Jesús y en los vv. 44.48 menciona la descalificación de Jesús: «vuestro padre el diablo, y queréis satisfacer los deseos de vuestro padre. Él era homicida desde el principio». El v. 48 presenta la respuesta de los judíos: «Respondieron los judíos y le di-

54 Cf. G Russell, The Method \& Message of Jewish Apocalyptic, 125-127.

55 D. Hare, The son of man Tradition, 87. 
jeron: $-{ }_{i}$ No decimos bien nosotros que tú eres samaritano y que tienes demonio?». Luego continúa con la respuesta de Jesús utilizando la terminología de Is 52, 13 acerca de la exaltación: «...cuando ("o $\tau \alpha \nu)$ hayáis levantado (i் $\psi \omega ́ \sigma \eta \tau \epsilon)$ al Hijo del hombre, entonces entenderéis que yo soy $(\dot{\epsilon} \gamma \omega \dot{\omega} \epsilon \dot{\imath} \mu \iota) »$.

Tanto la expresión «samaritano» como «endemoniado» remiten al vocabulario de la exclusión. La expresión "o $\alpha \alpha \nu$ la encontramos en relatos apocalípticos que describen los últimos tiempos de acuerdo a la serie de eventos que acontecerán en la historia ${ }^{56}$. Es significativo en este dicho la conexión entre ú $\psi \omega ́ \sigma \eta \tau \epsilon$-propia del destino del profeta mosaico isaiano- y la expresión egótica é $\gamma \omega$ ' $€$ i $\mu \iota$ aplicado no al «profeta», sino sobre la futura muerte del Hijo del hombre, anunciada a sus enemigos como requisito para comprender que este tiene vida en sí mismo (6, 49-50). Estas expresiones egóticas colocan en evidencia, en primer lugar, la intención del cuarto evangelio por relacionar el verbo «ser» con la naturaleza preexistente del enviado, en contraste con la de los otros emisarios de Dios, como pudieron ser los patriarcas Jacob o Abraham, o con las figuras o instituciones veterotestamentarias como el Éxodo, la Ley, el maná que comieron en el desierto, el pozo de Jacob, etc. En segundo lugar, mediante esta relación lingüística, el ser del Hijo se revela como superior al ser de los antepasados más renombrados como Abraham, Moisés o cualquier profeta; las figuras de tiempos pretéritos de la antigua alianza son superadas o adquieren su cumplimiento en la persona del enviado, el Hijo del hombre. De tal manera que la fe de la comunidad tiene un fundamento mayor que se traduce como «creer que Yo soy», es decir, es una fe en que el Hijo y el Padre son uno. Pero está superioridad expresa un carácter paradójico, pues se refleja en la solidaridad hasta la muerte en cruz.

\subsection{El dicho de Jn 9, 35}

El dicho de Jn 9, 35 se coloca en un contexto en que la recuperación de la vista pasa por un conflicto con los fariseos y judíos (vv. 13. 19) debido a que lo había realizado en día sábado. Al igual que Jn 15-18, el conflicto relatado en el capítulo 9 ya no es directamente con Jesús, sino a causa de la confesión cristológica sobre el Hijo del hombre: «crees tú en el Hijo del hombre» (v. 35), la cual contiene un carácter paradójico.

56 Cf. Mc 13, 28-29; Lc 21, 9. 20. 31; 1 Cor 15, 27). 
La relación felvisión, así como cegueralendurecimiento atraviesa, desde un comienzo, todo el cuarto evangelio y remite al principio de ignorancia propio de movimientos apocalípticos judíos. La expresión de 9, 35 «tú crees ( $\pi\llcorner\sigma \tau \in \dot{\epsilon} \in\llcorner\varsigma)$ en el Hijo del hombre» recuerda la de 3, 15 «todo el que cree (ó $\pi \iota \sigma \tau \in \cup ́ \omega \nu)$ en él tiene vida eterna», pues están vinculados por la imagen de contemplar a la serpiente en el texto de $\mathrm{Nm} 21,9$ o de creer en el Hijo del hombre $(9,35)$.

Este conflicto alcanza a sus seguidores, los que sufren la persecución y expulsión a causa de su confesión delante de los hombres: son expulsados y odiados por el mundo. El texto expone el proceso que lleva al ciego a ser excomulgado de la sinagoga, no relata solo la curación, sino también el endurecimiento y decisión de las autoridades judías de excomulgar a quienes confiesen el carácter mesiánico del Hijo del hombre: «... le dijo: -¿Crees tú en el Hijo del hombre?» (v. 35). El texto tiene claras referencias -así como otras secciones del evangelio- a la situación que vive la comunidad joánica donde los cristianos están amenazados con la expulsión de la sinagoga (vv. 22. 34. 35). La causa de esta confesión radica -a juicio del evangelista- en creer o reconocer que este es el Hijo del hombre y en que la ceguera es la increencia. En el pasaje de 12, 38-41, la increencia está fundado en el principio de ignorancia expresado por medio de una cita compuesta del profeta Isaías, Is 53, 1; 6, 10 (Jn 12, 3841): «para que se cumpliese la palabra del profeta Isaías que dijo: Señor, ¿quién ha creído a nuestro mensaje? [...] Por eso no podían creer, porque Isaías dijo en otra ocasión: -Él ha cegado los ojos de ellos y endureció su corazón, para que no vean con los ojos ni entiendan con el corazón, ni se conviertan, y yo los sane». La ceguera de los judíos cumple un misterioso plan divino, expresado en la profecía de Is 6,10 y recurrente en el primitivo cristianismo para mostrar el misterio del endurecimiento de Israel y el rechazo del pueblo elegido a los profetas (ver Mc 4, 11; 12, 1-11). Este misterio expresa, por medio de una ruptura epistemológica, la paradoja del fracaso de los enviados, que no obstante el sinsentido o final violento que sufren en su misión, a través de estos Dios realiza su salvación. Este es un mensaje de esperanza para la comunidad joánica que se encuentra en esta situación paradójico como lo muestra el v. 39: «...Para juicio yo he venido a este mundo; para que vean los que no ven, y los que ven sean hechos ciegos». 
3.7. El dicho de Jn 12, 23

El dicho está contextualizado dentro de una serie de referencias a la futura muerte del Hijo del hombre. De manera especial está en relación a la muerte de Lázaro. El sentido de la muerte de Lázaro está expresado en Jn 11, 14-15. 42. 45: «...Lázaro ha muerto, y me alegro por vosotros de no haber estado allí, para que creáis». Esto refuta la idea que el 20, 31 pertenece a una fuente de signos en la cual la cristología estaría centrada en la fe en el Mesías ${ }^{57}$. Y también en el v. 40: «...¿no te he dicho que si crees verás la gloria de Dios?». Los vv. 32.37 muestran las dudas o suspicacias en contra de Jesús. El sentido salvífico de la muerte de Lázaro - «para que crean»- se explica como una exhortatio ad martirium, es decir, para que ella y su propia muerte tenga efecto sobre la esperanza en la resurrección de los discípulos. El evangelista desarrolla esta sección apuntando a que el envío del Hijo del hombre está abocado a su muerte: "para esto he llegado a esta hora», esto es, "para que crean que tú me has enviado». La glorificación del Hijo del hombre está relacionada desde el cap. 11 con la muerte y resurrección de Lázaro (v. 17). La muerte del grano de trigo (v. 24) manifiesta el sentido (v. 27); a su vez, los vv. 24-25 son una exhortatio ad martirium de los discípulos ${ }^{58}$. La muerte de Lázaro cumple una intención soteriológica: por medio de su muerte muchos "creyeron en él» (en Jesús). En este aspecto es notable cómo el v. 48 contextualiza el riesgo que significa para la nación tener fe en el Hijo del hombre: «todos creerán en él, y vendrán los romanos y destruirán nuestro lugar santo y nuestra nación». Los vv. 50-53 muestran cómo el temor de que el pueblo siga a Jesús traerá el fin de la nación; en ese sentido, la profecía de Caifás manifiesta paradójicamente el sentido de la muerte de Jesús: «ni os dais cuenta de que nos conviene que un hombre muera por el pueblo, y no que toda la nación perezca [...] y no solamente por la nación, sino también para congregar en uno a los hijos de Dios que estaban dispersos. Así que desde aquel día acordaron matarlo».

Luego de la entrada a Jerusalén, el v. 16 representa un comentario del evangelista: «Estas cosas no las entendieron sus discípulos al principio,

57 Cf. J. Becker, «Wunder und Christologie», en NTS 16(1970)2, 133-135; D.A. Carson, "The purpose of the Fourth Gospel: John 20, 31 Reconsidered», en JBL 106(1987) 4, 639-651.

58 D. Frankfurter, Elijah in Upper Egypt. The apocalypse of Elijah and Early Egyptian Christianity (Miniapolis 1993), 141-147. 
pero cuando Jesús fue glorificado, entonces se acordaron de que estas cosas estaban escritas acerca de él, y de que se las habían hecho» (Jn 12, 16). La expresión "cuando Jesús fue glorificado» se refiere a la exaltación en los cielos, no en la cruz. Los discípulos Andrés y Felipe le llevan la solicitud de unos griegos que desean verlo. El dicho sobre el Hijo del hombre es un dicho de paso, pues la sección agrupa otros tres dichos relativos a esta figura. En este dicho: «Y Jesús les respondió diciendo: $-\mathrm{Ha}$ llegado la hora para que el Hijo del hombre sea glorificado ( $\delta \circ \xi \alpha \sigma \theta \hat{n}) »$ (v. 23) es la primera oportunidad en que Jesús afirma que la hora del Hijo del hombre es la hora de su crucifixión. La muerte de Lázaro, la profecía de Caifás, la imagen del grano de trigo y la exhortatio ad martirium son prueba del contexto martirial. La hora de Jesús es la hora de su muerte en la cruz. Al mismo tiempo, según 12, 31, la elevación es la hora del juicio del mundo, donde es expulsado el demonio.

El dicho está en relación a otro, ubicado en el v. 32 que dice: «cuando

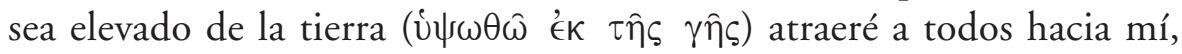
decía esto para dar a entender de qué muerte iba a morir». El sentido

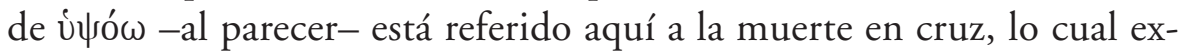
presa, como ha sido comentado por otros autores, un carácter insólito: la elevación ya no es postergada a una etapa posterior a la muerte sino que su misma muerte es el comienzo de su exaltación, esto es, su propio martirio es praxis de su esperanza. Pero ¿por qué el evangelista insiste en este carácter paradójico de úłó $\omega$ ? ¿Qué explica este sentido? Creemos que el hecho radica en que el evangelista ha querido insistir en reiterados momentos de su relato que el Hijo del hombre es superior al templo (2, 19); a los patriarcas $(4,12 ; 8,58)$; a los profetas $(5,46 ; 12,41)$; a la Ley $(5,17)$; a los ángeles y visionarios $(1,18 ; 3,13 ; 12,29)$ y las Escrituras $(1,45 ; 5,46)$ y esta superioridad paradójicamente corresponde al Hijo del hombre como mártir.

\subsection{El dicho de Jn 12, 34-36}

El contexto de este dicho es ante la «multitud» (vv. 29. 34). En esta sección está contextualizada no solo en relación a la muerte de Cristo -expresada en un ambiente de polémica y persecución de la comunidad joánica-, sino además que el sentido de la muerte es para que crean. Así p.ej. termina este párrafo en 12, 42 de modo semejante a 9, 35: «No obstante, aun de entre los dirigentes, muchos creyeron en él, pero por causa de los fariseos no lo confesaban, para no ser expulsados de la sinagoga». 
También como en 5, 4 se menciona la intervención de un ángel: «... Jesús y dijo: -No ha venido esta voz por causa mía, sino por causa de vosotros» (Jn 12, 29-30). La respuesta de Jesús deja en claro que «él se sitúa por sobre los ángeles», la voz a venido «a causa de vosotros», pero él está situado por sobre estos. Esto responde a la teología del martirio: el mártir está sobre los ángeles, pues a diferencia de aquellos, «este es capaz de dar la vida por Dios, y en el caso del Hijo tener vida en sí mismo». Esto se debe a que el martirio de Abel, y la muerte violenta de todos los profetas fue considerado desde tiempos precristianos como un misterio divino ${ }^{59}$. En este dicho sobre el Hijo del hombre aparece tres veces mencionado (vv. 23. 34. 35): una en Jn 12, 23: «...ha llegado la hora para que el Hijo del hombre sea glorificado $(\delta \circ \xi \alpha \sigma \theta \hat{n}) »$. También en Jn 12, 34-36 «Entonces la gente le respondió: -Nosotros hemos oído que, según la ley, el Cristo permanece para siempre. ¿Y cómo es que tú dices: "Es necesario que el Hijo del hombre sea levantado"? ( $\delta \in \hat{\imath}$ ù $\psi \omega \theta \hat{\eta} \nu \alpha \iota)$ ¿Quién es este Hijo del hombre?35. Es notable en este último dicho la dependencia de 3,13, donde se menciona la misma construcción sobre la necesidad de que el Hijo del hombre sea levantado. El v. 23 que habla de la hora, no menciona esto, por consiguiente, pareciera que este dicho hay que comprenderlo tomando en cuenta aquel de 3, 13 y 9, 35. En el dicho, son importantes las dos preguntas que presentan un origen apocalíptico. La primera, el uso de la expresión $\delta \in \hat{\imath}$, «es necesario», que es utilizado también en 3,14, para manifestar que el signo de la muerte del Hijo del hombre está entendida dentro del plan salvífico de Dios y que por tanto posee un carácter de señal escatológica. En el cuarto evangelio esta expresión integra tanto la muerte como la resurrección como puede apreciarse en Jn 20, 9. En este pasaje, la necesidad no solo está remitida a la muerte, sino también a la resurrección de entre los muertos "Pues aún no entendían la Escritura, que le era necesario resucitar de entre los muertos». En los sinópticos el uso de esta particular está en relación a los eventos escatológicos tanto de la muerte como de la posterior secuencia del eschaton. La segunda pregunta, acerca de la identidad del Hijo del hombre, continua el tema del mesías incognitus que está basado en el principio de ignorancia, típico de escritos apocalípticos y que atraviesa diversos relatos del evangelio ${ }^{60}$.

59 Cf. VidaAdán 1, 3; TAbraham III, 4; VII, 3-17

${ }_{60}$ Cf. $1,26.31 ; 33 ; 3,10.11 ; 4,22.42 ; 7,27 ; 9,29 ; 14,22$. 


\subsection{El dicho de Jn 13, 31-32}

El dicho está expresado en el contexto de la última cena, cuando Satanás entra en Judas: «Después del bocado, Satanás entró en él» (Jn 13, 27). En Jn 13, 31-32 dice: "Cuando ("O $\tau)$ Judas había salido, dijo Jesús: -Ahora es glorificado ( $\epsilon \delta \circ \xi \alpha \dot{\alpha} \sigma \theta \eta)$ el Hijo del hombre». El texto comienza con la expresión «cuando» como comienzo de los dolores escatológicos. La expresión ( $(\epsilon \delta \circ \xi \alpha \dot{\alpha} \sigma \eta \eta)$ está tomada de Is 52,13 , pero es notable como sigue en el v. 33: «Hijos míos me queda poco tiempo...», el cual representa una marca característica del estilo nosotros que remite el dicho de la redacción final del evangelio.

El dicho de Jn 13, 18-19 cumple la misma función retrospectiva de 12, 48. La muerte de Cristo dará testimonio de que el Hijo del hombre comparte con el Padre la vida en sí mismo: "para que se cumpla la Escritura: El que come pan conmigo levantó contra mí su talón. Desde ahora os lo digo, antes de que suceda, para que cuando suceda, creáis que Yo Soy». El relato coloca por primera vez, en escena al discípulo amado, figura que también encontramos en textos de Qumrán, quien pregunta por la identidad del traidor. Solamente quien comparte la intimidad y destino, el discípulo amado interroga al Maestro. Jesús responde con el gesto de dar el pan a Judas. Este motivo del discípulo amado está presente en tradiciones apocalípticas para presentar a patriarcas, profetas, al profeta escatológico y al mesías ${ }^{61}$. En Qumrán es citado para describir la pasión del Maestro de Justicia quien cita el salmo 41, 9: «Aun mi amigo íntimo, en quien yo confiaba y quien comía de mi pan, ha levantado contra mí el talón», esto muestra claramente que uno de los rasgos de la teología del martirio tanto en la comunidad de Qumrán (1QH ${ }^{a}$ xiii, 20, 23-24) como en la tradición sinóptica fue que el profeta de los últimos tiempos además del anuncio de buenas nuevas según el texto de Is 61, 1 le acompañaría una vida de sufrimientos. De la misma manera que en la comunidad de Qumrán la aparición del traidor y de la apostasía de la ultima hora representa uno de los signos de los últimos tiempos que acompañan al mesías.

${ }_{61}$ Cf. 4Q377 f.1 recto col. II, 5-12; CD-A col. III, 1-21 (=4Q269, 2); 4Q491' fr. 1; 4Q427; 4Q213 4QAramaic Levia; y 4Q522 fr. 9 col. II 


\section{RefleXión SISTEMÁticA}

\subsection{La cristología prejoánica del martirio y exaltación}

La cristología del Hijo del hombre es un buen ejemplo para mostrar cómo se aplica el mismo esquema ideológico a un lugar teológico como es el del martirio y persecución de la comunidad joánica. En este sentido, es importante atender cómo en el origen prejoánico del paradigma de la exaltación o del arrebato $-y$ su relación con otras cristologías presentes en el NT- se produce la misma constante. Esto significa que responde a un contexto martirial como el que encontramos en Fil 2, 9; Hch 2, 33; 5, 31, lo cual demuestra -según M. Black- que el uso isaiano de este pasaje pertenece a un tipo de cristología de la exaltación previa a su utilización en el cuarto evangelio y que "este ha adoptado y adaptado» ${ }^{62}$.

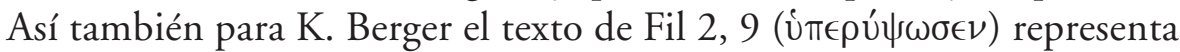
la prueba más antigua de una difundida tradición donde el destino postmortem de Jesús es descrito de un modo mítico como exaltación sobre los poderes ${ }^{63}$. En estas cristologías, tanto del himno de Flp 2, 6-11 y $\mathrm{Hb} 1-2$, son citados los textos de Is 52; Dn 12, 3; Sal 8, 4-6; 110, 1. El esquema cristológico es espacial y presupone una jerarquía de seres divinos y terrestres, los cuales el Hijo de Dios asume libremente «haciéndose semejante a los hombres y mostrándose en figura humana» ${ }^{64}$. A juicio de diversos autores el himno de Flp 2, 7-11 muestra el recorrido del Hijo de Dios, pero más que una "cristología de la exaltación»-como pretende Schnackenburg- lo que expresa es una teología del martirio, así lo confirma la situación personal de Pablo quien no solo menciona que está en la cárcel (vv. 1, 7. 13.14), sino que también considera su propia muerte como posible (vv. 20. 21); además en los vv. 29-30; 2, 1 presenta la exhortatio ad martirium como preámbulo al himno; dentro de este mismo, el v. 8c radicaliza la mención de la muerte humana sufrida por Cristo al añadir "y muerte de cruz». En el v. 9 utiliza el término «exaltación», lo cual tiene como efecto la superioridad del mártir: «Dios lo exaltó sobre todas las cosas y le dio un nombre que es sobre todo nombre». Esta superioridad es alcanzada gracias a la muerte en cruz del Hijo de Dios. De modo similar, en la carta a los $\mathrm{Hb}$ 1, 4 esta teología del martirio se

62 M. Black, «The Son of Man Passion Sayings in the Gospel Tradition», 6-7.

63 K. Berger, Theologiegeschichte des urchristentums, 211.

64 J. MaIER, Die Qumran-Essener (Münschen 1982), 136-137. 
expresa de modo similar en la expresión «tanto superior a los ángeles». La superioridad de la misión del Hijo está por sobre los ángeles, pues por la pasión y muerte «fue algo inferior a los ángeles, coronado de gloria y dignidad. Y lo pusiste sobre las obras de tus manos. Todo lo sujetaste bajo sus pies» (Hb 2, 7-8). El autor interpreta el Sal 8 de modo que «el Hijo es inferior a los ángeles por la pasión y muerte», pero por su resurrección "todo está sujeto bajo sus pies». Este esquema martirial es similar al encontrado en la cristología joánica.

Esta cristología «vertical» expresa una paradoja, pues muestra que en la encarnación del Logos se muestra la gloria del Padre y la superioridad del Hijo del hombre. En este sentido, la escena de Jn 19, 5 expresa esta paradoja que se explica por el radical contraste de esta escena con la pretensión del enviado divino. La afirmación de Bultmann refleja bien el contraste que pretende el evangelista: «[...] el sentido del evangelista ha colocado con esto, en una enorme imagen, toda la paradoja de la pretensión de Jesús. De hecho, es un hombre que afirma ser el rey de la

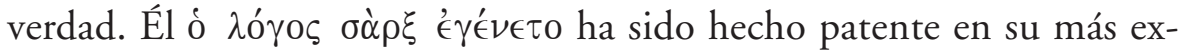
trema consecuencia» ${ }^{65}$. Sin embargo, Bultmann olvida que no hay mitos individuales sino solo para los pueblos. Para él, la paradoja de la muerte de Cristo se juega al margen de todo proceso social y político, la paradoja pareciera que radica en la oposición de los contrarios y no de una coyuntura martirial. Para nosotros, la paradoja radica en que la muerte y exaltación del Hijo del hombre está dirigido a una comunidad martirizada y para ello emplea una ideología apocalíptica, adaptando el motivo de la exaltación en la misma muerte en cruz pues la comunidad joánica comprende que la exaltación sigue el modelo presentado en el martirio del Hijo del hombre.

\subsection{El contexto y el modelo cristológico}

A partir de las reflexiones anteriores, parece cierto afirmar que la cristología del Hijo del hombre joánico remite a un lugar teológico, común a movimientos apocalípticos y grupos cristianos, que no solo podríamos llamar de polémica, sino sobre todo de persecución y conflicto con el judaísmo posterior al año $70 \mathrm{~d}$. C. Ciertamente es muy probable que el evangelista haya desarrollado la cristología del Hijo del hombre, para fundamentar la esperanza de esta comunidad, en una futura exaltación,

65 R. Bultmann, Das evangelium des Johannes, 510. 
en el contexto del enfrentamiento con los dirigentes judíos. El motivo del odio del mundo, la expulsión de la sinagoga, martirio y divisiones internas reflejan el mismo contexto teologal que hemos encontrado en tradiciones apocalípticas y en Qumrán. Este cambio de contexto explica que la cristología joánica evolucione debido a las condiciones sociales y políticas y no que esta se explique por una serie de estratos sucesivos que añaden elementos cristológicos foráneos a la misma matriz originaria. En relación a la cristología del Hijo del hombre, hay que decir que no se trata de que los dichos acerca de este personaje remiten a la muerte de este o sobre su posterior exaltación, sino que correctamente dicho, se refiere a la suerte de los cristianos en su experiencia contemporánea de persecución y martirio de la cual el Hijo del hombre es su paradigma. Como es muy probable -a la luz de nuestra investigación- que la cristología del Hijo del hombre radicaliza, profundiza la del profeta escatológico existente en grupos marginales del judaísmo tardío, hay que entender que esta profundización es a raíz de la propia experiencia de martirio y no como una corrección o un añadido posterior a una deficiente formulación de esta. Se trata entonces de que la figura del Hijo del hombre responde a un mismo lugar teológico; en este sentido, las diferencias de vocabulario, de estilo o de dichos tipo sinópticos son integradas, pero comprendidas desde un contexto martirial. Esto explica muy claramente por qué esta cristología está interesada en subrayar tanto la humanidad como muerte del Hijo del hombre. Si los grupos apocalípticos del judaísmo tardío habían desarrollado una teología sobre la gloria en forma de hombre -que representa un antecedente de una teología de la encarnación- debemos decir que el evangelio de Juan representa una radicalización de esta al señalar que el envío del Hijo del hombre conlleva su condición sárkica, oprimida y su muerte en Cruz. Como menciona Jn 1, 51, el Hijo del hombre está rodeado de ángeles, los términos $\kappa \alpha \tau \alpha \beta \alpha i \nu \omega$ y $\alpha \nu \alpha \beta \alpha i ́ \nu \omega$ están en relación a los ángeles que suben y bajan, pero estos bajan y suben sobre el Hijo del hombre. Esto aclara que el autor está interesado en demostrar que la superioridad del Hijo del hombre radica en ese hombre oprimido y que no solo alcanza a las instituciones judías sino también a los ángeles y, por tanto, el Hijo del hombre, por ser un oprimido, perseguido y mártir, que está en tierra, se sitúa sobre los seres celestiales. Esto mismo lo vemos en Jn 3, 13, donde el tono polémico del dicho no se entiende sino en relación a un judaísmo que cree en el envío de ángeles, pero el autor pretende reiterar 
que el Hijo del hombre tiene esa exclusividad, por eso el autor está interesado en legitimar al Hijo del hombre ante otros mediadores celestes o humanos, pero que no han pasado por la muerte. La cuestión de la superioridad del Hijo del hombre recorre el cuarto evangelio.

\subsection{La martirio del Hijo del hombre y el uso del término u廿ów}

Como lo hemos indicado en nuestra introducción, diversos autores han sostenido que uభów está en relación a la muerte en cruz y no a la exaltación en los cielos. En el cuarto evangelio se utilizan diversos términos para describir el «regreso" del enviado, p.ej. $\alpha \nu \alpha \beta \alpha i \nu \omega(1,52 ; 3,13$;

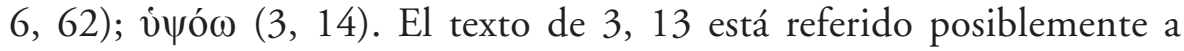
su preexistencia y el v. 14 en relación a su exaltación. Como lo hemos comprobado, la diferencia de vocabulario no es argumento definitivo para expresar diferentes estratos o fases de la cristología joánica, más bien muestra la concurrencia de diferentes materiales o tradiciones apocalípticas relativas al Hijo del hombre. Para Moloney, en el cuarto evangelio no hay un ascenso del Hijo del hombre a los cielos, sino que esto acontece en su muerte. Este autor subraya una y otra vez que «la glorificación de Cristo ocurre en la cruz y no continúa en los cielos» ${ }^{66}$. A nuestro juicio, la posición de Moloney sostiene que la idea del Hijo del hombre está unida íntimamente a la cruz, pero olvida mencionar las expresiones que se refieren al tema del regreso al Padre ${ }^{67}$. Por otra parte, F. Moloney argumenta que el background de esta idea está en la interpretación de Dn 7 que interpreta al Hijo del hombre no como una figura celeste, sino como el pueblo de los santos del altísimo que sufren bajo las cuatro bestias, por tanto, hace referencia a un esquema martirial. En su perspectiva lo fundamental radica en que «el Hijo del hombre es una figura que adquiere autoridad a través del sufrimiento» ${ }^{68}$. En este último punto, Moloney está en lo correcto, pero esto no se basa solo en el texto de Dn 7, sino en una larga tradición martirial. Lo fundamental radica -como efectivamente lo señala la exégesis europea- en que los dichos sobre el Hijo del hombre están en relación a su muerte o su exaltación, pero fallan en entender esta muerte en sentido individualista al no contextualizar la reflexión sobre ułó $\omega$ como producto de una teología del

66 F. Moloney, The Johannine Son of Man, 229.

${ }_{67}$ Cf. $8,14.21 ; 13,33 ; 14,3.4 .12 ; 16,5.10 .17 .28 ; 17,11.13$.

68 P. Moloney, The Johannine Son of Man, 236-237. 
martirio. En estos textos no existe propiamente hablando una cristología de la exaltación sino una teología del martirio.

\subsection{La preexistencia y el Hijo del hombre}

Anthony T. Hanson ha llamado la atención sobre el supuesto de la actividad preexistente del Logos en el AT. Este presupuesto lo encontramos en el pensamiento paulino ${ }^{69}$. Mucho se ha hablado de la relación entre el pensamiento paulino y joanismo. Aquí solo haremos relación a la idea de preexistencia de Cristo en el Antiguo Testamento.

En Jn 12,41 sostiene que el profeta Isaías «vio la gloria y habló acerca de él ${ }^{70}$. El evangelista cita los pasajes de Is 6,9 s y 53 , 1, el primero está referido al misterio del endurecimiento de Israel y el segundo a la misión del siervo de Yahvéh ${ }^{71}$ (ver Rm 10, 16). Son significativas estas citas isaianas, pues la primera se refiere a la actividad preexistente de Cristo en el AT y la otra al misterio del endurecimiento de Israel. La primera pertenece a la cristología del profeta escatológico, la segunda explica la situación del judaísmo contemporáneo que vive la comunidad joánica. De acuerdo a esto, Isaías habría tenido la visión de la gloria de Hijo del hombre. Esto mismo es señalado en Jn 8, 56: «Abraham, vuestro padre, se regocijó de ver mi día. Él lo vio y se gozó». Este texto está en el contexto de discusión con judíos que se consideran hijos de Abraham. Cristo responde con el dicho: «antes de Abraham, yo soy». La misma idea está en Jn 5, 46: «Porque si vosotros creyeseis a Moisés, me creeríais a mí; pues él escribió de mí». Es importante distinguir entre preexistencia y tipología. La idea de la preexistencia de Cristo en el AT está relacionada con la ideología apocalíptica sobre la gloria en forma humana de Ez 1, 26 y 1Enoch 14. Así también la afirmación de que Moisés escribió sobre Cristo está en relación a la transfiguración de gloria en forma de hombre que encontramos en textos apocalípticos. Además, se relaciona con Moisés y la revelación de la Gloria de Cristo en el tabernáculo El evangelista -al parecer- remite al texto de Ex 34, 27-35 donde Moisés baja de la montaña transfigurado. Es importante señalar que en estos pasajes no trata de una tipología, sino que se postula la presencia real de

${ }_{69}$ Cf. 1Cor 10, 1-11; 2Cor 3, 7-18; Rm 10; 9, 28; 11, 3

70 A. Hanson, Jesus Christ in the Old Testament (London 1965), 104-126.

71 A. Hanson, Jesus Christ in the Old Testament (London 1965), 104-126. De la misma manera que Moisés en Rm 11, 7; 11, 25. 
Cristo en el AT. En textos como Jn 3, 13; 6, 62 se menciona la preexistencia del Hijo del hombre. Se equivoca D. Hare al referirse a 6, 62 donde habla directamente de la preexistencia de alguien, pero no acepta que sea "una referencia a una precristiana tradición concerniente a un hombre celeste» ${ }^{72}$. Nos parece que las afirmaciones sobre la preexistencia representaron un punto neurálgico de la polémica con la sinagoga judía ya que sostenía claramente la "doctrina de dos poderes» existente en grupos apocalípticos. En cambio en textos como Jn 1, 45 se da más bien una interpretación tipológica: "Hemos encontrado a aquel de quien Moisés escribió en la Ley, y también los Profetas: a Jesús de Nazaret». La idea de la preexistencia de Cristo en el AT -presente también en el paulinismo- refuerza y profundiza el argumento de la tipología, debido a que la historia de salvación ha sido guiada por el mismo Verbo preexistente. Esto muestra que el tema de la preexistencia no tuvo en sus orígenes, en primer lugar, el sentido de la igualdad de naturalezas con el Padre, sino que tiene un sentido histórico-salvifico, pero trascendente, fundado en una comprensión mítica de la historia que pretende radicalizar la lectura mesiánica del AT, afirmando que la gloria del Padre -Cristo- estaba presente en la historia de Israel (ver Jn 1, 10).

\section{Conclusiones}

Al final de estas reflexiones es importante subrayar que la cristología del Hijo del hombre joánico ha sido elaborada desde una situación teologal de persecución y martirio presente en grupos joánicos que habían experimentado el rechazo y la persecución. La experiencia martirial de estas comunidades representa un lugar teológico desde donde se pretende fundamentar la esperanza en una futura exaltación. Hay que subrayar que esta teología del martirio expone el valor trascendente para Dios, de mártires como Abel, Elías y todos los profetas, que lucharon hasta la muerte por la justicia divina. Son estos mártires de la antigüedad y los futuros quienes son portadores de la esperanza de una futura exaltación. Estos datos responden al curioso hecho teológico -no suficientemente aclarado- de la repentina creación ex nibilo de la comunidad postpascual palestinense o helenista del sentido soteriológico de la muerte de Cristo en la cruz. En verdad, el cristianismo naciente comprendió el sentido de la muerte de Cristo asumiendo una teología del martirio,

72 D. Hare, Son of Man Tradition, 100. 
presente en textos judíos preexistentes que hablaban de la exaltación del mártir, a partir de la cual ha desarrollado el sentido de la muerte de Cristo.

Hemos mostrado en nuestra reflexión que los dichos sobre el Hijo del hombre utilizan un mismo "pacto comunicativo o pragmático» común a grupos apocalípticos, lo cual explica tanto la perspectiva, temas teológicos como términos utilizados en los dichos. Esta teología del martirio, es una teología de la esperanza, que se elaboró desde una situación teologal de persecución y martirio, asume el principio de ignorancia típico de la apocalíptica según el cual los judíos «no saben», son "ciegos», «no ven», etc., en cambio a los discípulos se les promete que «verán los cielos abiertos» $(1,51 ; 3,11)$; así también adopta la terminología del descenso como del martirio y de la exaltación. La finalidad de los dichos sobre el Hijo del hombre joánico pretenden exhortar, en un contexto martirial, a la esperanza, al valor del testimonio de los discípulos del Hijo del hombre por sobre otras instituciones, a esto se debe la exposición sobre la superioridad del Hijo del hombre, la exhortación al martirio y el valor de su entrega hasta la muerte. Si bien es cierto que el evangelista ha desarrollado esta cristología del Hijo del hombre en base a esquemas teológicos judíos relativos al martirio, su importancia se coloca en evidencia al enfatizar que la supremacía del Hijo del hombre radica no en una llamada a la esperanza por sí misma, sino en el carácter paradójico de esta, es decir, la mayor esperanza se fundamenta en la radical solidaridad del Hijo del hombre con el hombre. 
Resumen: El artículo desarrolla las características fundamentales de la cristología joánica del Hijo del hombre y explica los principales aspectos presentes en los dichos relativos a esta figura, sosteniendo que estos provienen de una tradición relativa al martirio del pueblo originada en ambientes judíos apocalípticos marginales críticos a un judaísmo oficial. Esta teología martirial se constituye en una legitimación frente a un judaísmo institucional y excluyente. La hipótesis muestra que entre contexto martirial y elaboración teológica del martirio y exaltación existe una vinculación más determinante de lo que propone L. Martyn y R. Brown. La experiencia de persecución funciona como lugar teológico desde donde la comunidad joánica desarrolla una teología del martirio similar a la de grupos apocalípticos del judaísmo. El aporte del evangelista a esta teología radica en que los dichos expresan la paradójico superioridad del Hijo del hombre -encarnado y entregado a la muerte- frente a todas las instituciones judías.

Palabras clave: Cristología, hijo del hombre, cuarto evangelio, esperanza, martirio, exaltación

Abstract: The paper develops the fundamental characteristics of Johannine Christology of the Son of man and explains the main aspects present in statements about this figure, claiming these come from a tradition related to martyrdom of the people originated in apocalyptic marginal Jewish environments which are critical of official Judaism. This theology of martyrdom constitutes a legitimation with regard to an institutional and exclusive Judaism. The hypothesis shows that there is a link between the context of martyrdom and the theological development of martyrdom and exaltation which is more determining than what is proposed by L. Martyn and R. Brown. The experience of persecution functions as a theological place from where the Johannine community develops a theology of martyrdom similar to the one of apocalyptic groups of Judaism. The evangelist's contribution to this theology is that the statements express the paradoxical superiority of the Son of man -incarnated and delivered unto death- in face of all Jewish institutions.

Keywords: Christology, Son of man, fourth gospel, hope, martyrdom, exaltation 